\title{
VALUES OF AKHLAK EDUCATION BASED ON SULUK TAREEQA NAQSYABANDIYAH KHOLIDIYAH
}

\author{
Setyo Pambudi \\ Pascasarjana Doktoral Universitas Islam Negeri Sunan Kalijaga Yogyakarta, Indonesia \\ pambudis650@gmail.com \\ Ahmad Wahyu Hidayat \\ Pascasarjana Doktoral Universitas Islam Negeri Sunan Kalijaga Yogyakarta, Indonesia \\ ahmadwahyuhidayat95@gmail.com
}

Received: 13-04-2020 Revised: 09-07-2020 Accepted: 16-07-2020

\begin{abstract}
This study raises the theme of the values of Moral-Based Moral Education in the Naqsyabandiyah Kholidiyah Islamic Boarding School of Al-Manshur Popongan Klaten. The research method used is qualitative method, using the one used is phenomenology, the subject is the Murshid of the Naqshabandiyah Khalidiyah Order, the Naqshyabandiyah Khalidiyah Congregation and religious figures around the popongan Islamic boarding school, analyzing the data using structured analysis methods, monitoring, and triangulation of data. The results of his research are: 1) Moral Education in the Procession of Suluk Tarekat Naqsyabandiyah Kholidiyah Boarding School Al-Manshur Popongan Klaten. Based on the content of the requirements and the harmony of the above, that in the procession of suluk it takes the values of moral education that is able to improve the quality of human beings to be perfect beings. And in it there are morals towards Allah SWT, Teachers, Students and Fellow. The implementation of suluk can also be actualized in social life, 2) Values of moral education in the Suluk Naqsyabandiyah Kholidiyah pesantren Al-Mansur Boarding School in Klongan. That contains moral education which includes: 1 . Morals towards God, namely Repentance, Gratitude, Tawakal, and Ikblas. 2. Morals towards Teachers, namely Ridho, Ta'drim, Obedience and Amanah. 3. Morals towards Yourself, namely Sidiq, Mujahadah, Istiqomah and Wara'. 4. Morals towards Others, C) Implementation of Suluk Naqsyabandiyah Kholidiyah in Community or Daily Life. 1. Ukhuwah Islamiyah, 2. Tawadhu', 3. Ta'awun and 4. Husnudzan
\end{abstract}

Keywords: Morals, Suluk Tarekat Naqsyabandiyah Kholidiyah

\begin{abstract}
Abstrak
Penelitian ini mengangkat tema Nilai-Nilai Pendidikan Akblak Berbasis Suluk Tarekat Naqsyabandiyah Kholidiyah Pondok Pesantren Al-Manshur Popongan Klaten. Metode penelitia yang digunakan yaitu metode kualitatif, pendekatan yang dipakai yaitu pendekatan fenomenologi, subjeknya yaitu Mursyid Tarekat Naqsyabandiyah Khalidiyah, Jamaah Tarekat Naqsyabandiyah Khalidiyah dan Tokoh agama di lingkungan sekitar pondok, pesantren popongan, analisi datanya dengan metode wawancara terstruktur, observasi, dokumentasi serta triangulasi data. Hasil penelitiannya yaitu: A) Pendidikan Akblak dalam Prosesi Suluk Tarekat Naqsyabandiyah Kholidiyah Pondok Pesantren Al-Manshur Popongan Klaten. Berdasarkan Kandungan Syarat dan rukun suluk diatas maka bahwasanya di dalam prosesi suluk terdapat nilai-nilai pendidikan akblak
\end{abstract}


yang amampu untuk memperbaiki kualitas diri manusia menjadi insan yang sempurna. Serta didalamnya terdapat akblak terhadap Allah SWT, Guru, Murid dan Sesama. Pelaksanaan suluk juga dapat diaktualisasikan dalam kebidupan bermasyarakat, B) Nilai-nilai pendidikan akblak dalam suluk tarekat Naqsyabandiyah Kholidiyah Pondok Pesantren Al-Manshur Popongan Klaten. Babwasanya mengandung pendidikan akblak yang meliputi: 1. Akblak terbadap Allab, yaitu Taubat, Syukur, Tawakal, dan Ikblas. 2. Akblak terbadap Guru, yaitu Ridho, Ta'drim, Taat dan Amanah. 3.Akblak terhadap Diri Sendiri, yaitu Sidiq, Mujahadah, Istiqomah dan Wara'. 4. Akblak terbadap Sesama, C) Implementasi Suluk Naqsyabandiyah Kholidiyah dalam Kebidupan Bermasyarakat atau sehari-hari. 1. Ukhuwah Islamiyah, 2. Tawadhu', 3.Ta'awun dan 4. Hunuzzan

Kata Kunci: Akblak, Suluk Tarekat Naqsyabandiyah Kholidiyah

\section{INTRODUCTION}

Education as an effort to humanize humans is basically an effort to develop the potential of every individual so that they can live optimally, both as individuals and as part of society, and have moral and social values as a guide to their lives ${ }^{1}$. Thus education is seen as a conscious effort aimed at and efforts to mature children. ${ }^{2}$ As the concept of Western education, Islamic education is education that is aware of the goals of even Islamic education has the most prominent characteristics of the goal, which is characterized by religion and morals $^{3}$. The overall nature that covers all aspects of the student's personal and all aspects of development in society. The goal is clear and balanced, there is no conflict between the elements with the ways of their implementation. ${ }^{4}$

Seyyed Hossein $\mathrm{Nasr}^{5}$ in his book Traditional Islam in the Modern World explicitly states that tradition implies something sacred when conveyed to humans through revelation and the disclosure and development of sacred roles in certain human history as a way to imply. both horizontal continuity with Original and vertical sources that connect each pulse of the life of the tradition being discussed with the meta-historical reality of transcendence.2 More clearly, Seyyed Hossein Nasr details tradition with three characteristics: the sacred tradition

1 Muhammad Amri, Saharuddin Saharuddin, and La Ode Ismail Ahmad, "The Implementation of Islamic Education: The Process of Instilling Akhlakul Karimah (Noble Characters) for Madrasah Tsanawiyah Students," Tadris: Jurnal Keguruan Dan Ilmu Tarbiyah 4, no. 1 (June 28, 2019): 117-25, https://doi.org/10.24042/tadris.v4i1.4070; Hasan Baharun and Rohmatul Ummah, "Strengthening Students' Character in Akhlaq Subject Through Problem Based Learning Model," Tadris: Jurnal Keguruan Dan Ilmu Tarbiyah 3, no. 1 (June 29, 2018): 21-30, https://doi.org/10.24042/tadris.v3i1.2205; Chairul Anwar et al., "The Effectiveness of Islamic Religious Education in the Universities: The Effects on the Students' Characters in the Era of Industry 4.0," Tadris: Jurnal Keguruan Dan Ilmu Tarbiyab 3, no. 1 (June 29, 2018): 77-87, https://doi.org/10.24042/tadris.v3i1.2162.

${ }^{2}$ Nana Sudjana, Pembinaan Dan Pengembangan Kurikulum Di Sekolab (Bandung: Sinar Baru Al Gensindo, 1991).

3 Nana Herdiana Abdurrahman, "Character Education in Islamic Boarding School- Based Sma Amanah," Jurnal Pendidikan Islam 2, no. 2 (June 21, 2016): 287-305, https://doi.org/10.15575/jpi.v2i2.791; Muhammad Anas Ma`arif and Muhammad Husnur Rofiq, "Dzikir Dan Fikir Sebagai Konsep Pendidikan Karakter: Telaah Pemikiran KH. Munawwar Kholil Al-Jawi," Tadrib 5, no. 1 (July 1, 2019): 1-20, https://doi.org/10.19109/tadrib.v5i1.3066.

4 Omar Muhammad al-Toumy Al-Syaibany, Falsafah Pendidikan Islam (Terj. Hasan Langgulung), Cet. I (Jakarta: Bulan Bintang, 1979).

${ }^{5}$ Seyyed Hossein Nasr, Traditional Islam in the Modern World, 1st pbk. ed (London; New York: K. Paul International : Distributed by Routledge, Chapman \& Hall, 1990). 
revealed by God to various religions through revelation in context different times and places ${ }^{6}$. Traditions always don't change because they contain continuity, contains knowledge about absolute reality and ways to actualize and realize knowledge in different places and times. Clear tradition is a call from the center of existence, containing metaphysical and always radiating truths that originate from transcendent reality ${ }^{7}$.

The success of a number of teachers who have guided the teaching of the order of Suata attachment to dhikr or wirid-wirid techniques in particular, means that the mechanism of student-teacher relations has been explained in a standard manner. ${ }^{8}$ Tariqa can free the human soul from earthly shackles and can deliver it out of the realm of painful alienation he feels for the universe. ${ }^{9}$ Mysticismis the endeavor to take the path to God, solely to seek His good pleasure ${ }^{10}$. The nature of suluk is an effort, earnest endeavor to cleanse themselves spiritually and physically, by repenting and emptying oneself from bad qualities (immoral or immoral behavior) mental), and fill it with praiseworthy, obedient and mental qualities. Everyone who suluk believes, that he will be clean and repentance will be accepted by Allah SWT, so he becomes taqarrub, close to Him ${ }^{11}$.

On a practical level, modern people today make many pilgrimages to the guardian's grave, remembrance to be closer to God secretly (khalwat) in the tarekat room, mass mobilization in 'urban Sufi' groups through spiritual performance in the Indonesian Remembrance Council, Hijrah Management Qalbu Fest, Mafia Shalawat, Shalawat Ahbabul Musthofa, Sima'an al-Qur'an Mantab, Dhikrul Ghafilin. In addition, some activities are packaged in a modern way using electronic and digital technology that is published through the printing industry, $\mathrm{TV}$, internet, and some of them are packaged in traditional-conventional ways such as tarekat in rural areas ${ }^{12}$.

The existence of the Naqshbandiyah order in the Al-Mansur Islamic Boarding School, Popongan is inseparable from the worldwide tarekat network. The Naqshbandiyah sect in Central Java originated from the well-known cleric, Sulaiman Al-Zuhdi with his zawiyah in Jabal Qubais. Distribution of this tarekat through intermediaries (clear genealogy) ${ }^{13}$. One of the fastest growing tarikats in Indonesia is the Naqsabandiyah tarikat which was founded by

${ }^{6}$ Seyyed Hossein Nasr, Islamic Philosophy from Its Origin to the Present: Philosophy in the Land of Prophecy, SUNY Series in Islam (Albany: State University of New York Press, 2006).

7 Arifin Arifin, Hasan Asari, and Amroeni Drajat, "The System of Spiritual Education of Tarekat Sammaniyah at Learning Assembly of Ihya Ulumuddin Medan," International Journal on Language, Research and Education Studies 1, no. 1 (2017): 34-52.

${ }^{8}$ Mahyunir, "Pemikiran Al-Ghozali Seputar Tradisi Sufi," Niæham 4, no. 2 (2015): 1-20.

9 M. Faiz, "Unsur Sufisme Dalam Konsep Pendidikan Said Nursi," Niæ̧ham 4, no. 2 (2015).

${ }^{10}$ Annemarie Schimmel, Mystical Dimensions of Islam (Jakarta Selatan: Mizan, 2013).

11 Muhammad Anas Maarif et al., "Character Education Through Dhikr Tariqa Qadiriyya Naqhsabandiyya Al-Usmaniyya Indonesia," Hampstead Psychological Associates 24, no. 07 (2020): 9.

12 William C. Chittick, "On the Cosmology of Dhikr," Within Paths to the Heart: Sufism and the Christian East (Edt. James S. Cutsinger), Indiana: World Wisdom, 2004, 55-56; Arif Zamhari, "THE MAJLIS DHIKR OF INDONESIA: Exposition of Some Aspects of Ritual Practices," JOURNAL OF INDONESLAN ISLAM 3, no. 1 (June 1, 2009): 122-147-147, https://doi.org/10.15642/JIIS.2009.3.1.122-147.

13 Jainudin Jainudin, "Pendidikan Karakter Dan Pergeseran Sosiopsikologis Penganut Aliran Tarekat Qadiriyahwanaqsabandiyah Surabaya," JOIES: Journal of Islamic Education Studies 1, no. 2 (December 4, 2016): 247-76, http://joies.uinsby.ac.id/index.php/joies/article/view/13; Moh Taufiq, "Pola Pendidikan Berbasis Tareqat Qadiriyah Wan Naqsabandiyah Di Pondok Pesantren Assalafi Al-Fitrah Surabaya," Jurnal Pendidikan Agama Islam Journal of Islamic Education Studies) 5, no. 1 (May 2, 2017): 138-60, https://doi.org/10.15642/jpai.2017.5.1.138160. 
Sheikh Muhammad Baharuddin, developing and branching out in several regions of the Asian continent such as China, Turkey, the Volga Ural and Java. In its development, this tarekat spread to Anatolia (Turkey) and then expanded to India and Indonesia with various new names adapted to its founders in the area, such as the Khalidiyah Tarekat, Muradiyah, Mujaddiyah, and Ahsaniyah. ${ }^{14}$

Many institutes develop their influences by opening sub-development of formal educational institutions, pesantren (schools of Koranic studies for children and young people, most of whom are boarders), business, hospital and psychological therapist counseling is evidence for opening the tarekat institution for epoch development. ${ }^{15}$

Naqsyabandiyah as one of the names of the tarekat which proved to exist in the Islamic world for 8 centuries (12-20 AD) because it successfully carried out Islamization with a cultural approach. Seclusion of a dog or 'seclusion in the crowd' as the main method of training and spiritual discipline to maintain Islamic beliefs and values from the various crises of modern human life that cause spiritual emptiness. The notion that khalwat causes someone to be exclusive to their environment is very interesting to study ${ }^{16}$.

The author found the facts of the problem in the field that the followers of this congregation were willing to leave their families and work for 10 days to 40 days to perform suluk or khalwat worship in certain months including Muharam, Maulid, Ramadhan and Rojab at the Suluk Pondok Pesantren Al-Manshur Popongan, Tegal Gondo, Wonosari, Klaten in accordance with the provisions of the Sheikh and his Khalifah. At the Pondok educational and teaching activities were held Tarikat Naqsabandiyah. Naqshbandiyah Tarikat appears in this area among the community as a congregation (organization) that has a stratification (level) from Sheikh Murshid, Caliph, Disciple and Wasilah which in their teachings develop certain remembrances in the practice of suluk or khalwat in order to cleanse the heart to reach spiritual degrees. tall one

From the background of the problem outlined above, the researcher formulated the problem as follows: How is the Implementation of Moral Education in the Suluk Process of the Naqsyabandiyah Kholidiyah Al-Manshur Popaten Klaten, How the Values of Moral Education contained in the Suluk of the Naqsyabandiyah Kholidiyah Al-Manshur Congregation of the Klongan Klongan Popongan, How to Actualize Values of Moral Education in life in the Community.

\section{METHOD}

The method used is to use research with a qualitative approach, which describes the object under study in the form of humans and goods based on facts and actual conditions. In this study the authors used a phenomenological approach (conclusion) to find out the results of excavation of suluk-based moral education.

\footnotetext{
${ }^{14}$ Rosihon Anwar Solihin, Ilmu Tasawuf (Bandung: Pustaka Setia, 2008).

15 Acep Aripudin, “Tarekat Qadariyah In Indonesia : Da Wa, Education and Business," Tasamub 12, no. 1 (2014): 1-20.

16 Firdaus Firdaus, “Tarekat Qadariyah Wa Naqsabandiyah: Implikasinya Terhadap Kesalehan Sosial," Al-Adyan 12, no. 2 (January 5, 2018): 55-72, https://doi.org/10.24042/adn.v12i2.2109; Luqman Abdullah, "Kontribusi Tarekat Naqsabandiyah Terhadap Pendidikan Agama Islam Dan Perubahan Perilaku Sosial Jamaah," Ną̧hruna 1, no. 1 (February 23, 2018): 1-13, http://ejournal.ikhac.ac.id/index.php/NAZHRUNA/article/view/82.
} 
Data Sources What is meant in this research are subjects and objects from which data can be obtained. ${ }^{17}$ According to Suharsimi Arikunto, research subjects are objects, things or people where data for the research variables are attached and are at issue. Interviewee or informantThis research is a Murshid, Badal and Salik of the Naqsyabandiyah Khalidiyah Tariqa in the Klaten Al-Manshur Islamic Boarding School in Klaten. In this case the researcher selected three people from several salik participants. As for the other Salik is an additional variable. these three people were selected from a number of participants who in fact had long followed the Suluk Naqsyabandiyah Kholidiyah at Pondok Popongan Klaten.Objects are anything in the form of what is determined by researchers to be studied so that information is obtained about it and then drawn conclusions. The object here can also be referred to as a variable. Objects can also be attributes of certain scientific fields or activities. Height, weight, attitude, motivation, leadership, work discipline, etc. ${ }^{18}$ In this case the data obtained in the form of writing, books and other documents are used to strengthen the findings in the field so that the data on the role of the Naqsyabandiyah Khalidiyah Khalidiyah Congregation of the Al-Manshur Islamic Boarding School in Klaten can be fully revealed.

The researchers collected written material such as news in the media, minutes of meetings, correspondence and reports to find the information needed. ${ }^{19}$ Researchers conducted direct observations at the research location at the Al-Mashur Islamic Boarding School in Klaten, namely the Suluk Tarekat Naqsyabandiyah Kholidiyah. The meaning of direct research is: the researcher directly interacts with the congregation of the Suluk Tarekat Naqsyabandiyah Khalidiyah and religious leaders who are around the Al-Mansur Boarding School.

To find objective data, the researchers used observation, interviews and documentation as primary and secondary methods to obtain the required data. The type of data used is qualitative data, because this study seeks to reveal the nature of nature. ${ }^{20}$ Data collection techniques are the most strategic step in research, because the main purpose of research is to get data. Without knowing data collection techniques, the research will not get data that meets the data standards applied. ${ }^{21}$

Observation is data to obtain knowledge about the problem to be studied. ${ }^{22}$ Oleh karena itu peneliti melaksanakan kegiatan observasi ini dalam bentuk partisipatif.Sehingga peneliti mengadakan pengamatan terhadap objek baik secara langsung maupun tidak langsung dengan menggunakan pedoman observasi. Peneliti dalam hal ini, mengadakan observasi dengan mengikuti kegiatan Suluk Tarekat Naqsyabandiyah Khalidiyah. Begitu pun peneliti mengikuti kegiatan yang dilakukan diluar suluk yaitu kegiatan yang dilakukan dirumah-rumah para jamaah Tarekat Naqsyabandiyah Kholidiyah. Begitupun juga peneliti mengamati keadaan lingkungan sekitar Pondok Pesantren Al-Manshur Popongan Klaten.

Interview which is a meeting of two people to exchange information and ideas through questions and answers. So that the meaning can be constructed in a particular topic.

${ }^{17}$ Suharsimi, Prosedur Penelitian (Jakarta: Rineka Cipta, 2014).

18 Sugiyono, Metode Penelitian Kuantitatif, Kualitatif Dan R\&D (Bandung: CV. Alfabeta, 2011).

19 Afrizal, Metode Penelitian Kualitatif (Depok: Raja Grafindo, 2014).

${ }^{20}$ Umam U. Dkk, Metode Penelitian Agama: Teori Dan Praktek (Jakarta: Raja Grafindo, 2006).

${ }^{21}$ Sugiyono, Metode Penelitian Kuantitatif Kualitatif Dan R\&D (Bandung: Alfabeta, 2015).

22 Sugiyono. 
Researchers conduct interviews, both directly and indirectly to the data source using the interview method ${ }^{23}$. The interview guidelines are not structured. Researchers in this case interviewed the Murshid of the Naqsyabandiyah Khalidiyah Congregation, the Naqsyabandiyah Khalidiyah Congregation and the Religious Leaders in the surrounding environment. Documentation, that is, researchers collect data from several important documents, such as archives that support the completeness of this research data. In this study,

\section{Suluk Tarekat Naqsyabandiyah Kholidiyah}

The term mysticism in Islam, tarikat means the journey of a Salik, (follower of the tarekat) towards God by purifying oneself or the journey that must be taken by someone to be as close to God as possible. ${ }^{24}$ Tariqat a way, way, school, or guidance in performing a worship in accordance with what is exemplified by the Prophet Muhammad. ${ }^{25}$ Tariqa can be interpreted as a system of living together and togetherness in diversity as an effort to spiritualize understanding and practice the teachings of Islam towards the achievement of Ma'rifatu'l. In this perspective, this formulation can be interpreted as a collective effort in tazkiyah al-nafs efforts in the framework of religious interiorization. ${ }^{26}$

Some Sunnis, although accepting the existence of the tarekat, but still oversees the practice tarekat and its intuition so as not to fall into deviant practices. Organization like NU, felt it was necessary to stipulate provisions on which tarekat were legal or mu'tabarah and illegitimate (ghairu al-mu'tabarah). ${ }^{27}$

Mysticismis an attribute of tarekat, while tarekat is an extension of Sufism. This expression indicates that suluk is a method of application of the concept of Sufism. Various concepts of Sufism were revealed by experts and researchers as mediators in developing methods and deepening monotheism, where the tarekat was again applied in the form of suluk, while making the quantity of worship increase. A Sufi who is then called the 'Shaykh' develops and empowers his students in a suluk way. ${ }^{28}$

Mysticismexisting in the tarekat, aims to foster students into human beings who are devout worship, have a healthy spiritual and mental. The position of suluk in attachment becomes a means for students to reach the goal of Sufism, which is to reach a high level and degree in the sight of Allah. Namely, muqarrabin (people who are close to God), through the way of worshiping Him. 2 Suluk activities are filled with various practices of dhikr with various patterns. There are patterns of forgiveness (asking forgiveness), prayer beads (praising), tahlil (raising), tahmid (worshiping), prayer (asking) and so on. The activity of dhikr more influences spiritual aspects, where students can integrate and interact with various patterns in dhikr according to the guidance of the sheikh.

23 John W. Creswell, Qualitative Inquiry \& Research Design: Choosing among Five Approaches, 2nd ed (Thousand Oaks: Sage Publications, 2007).

${ }^{24}$ Dewan Redaksi, Ensiklopedi Islam, Cetakan II (Jakarta: Ikhtiar Baru Van Hoeve, 1994).

25 Istadiyantha, Tarekat Syattariyah (Solo: Bina Insani Press, 2007).

${ }^{26}$ Amrizal Isa and Riki Astafi, "The Existing of Naqshbandi Tariqa and Its Influence on Socio-Cultural Life of the Sakai People in Bengkalis Regency," Wawasan: Jurnal Ilmiah Agama Dan Sosial Budaya 4, no. 1 (2019): 80-93, https:/ / doi.org/10.15575/jw.v4i1.4072.

${ }^{27}$ Fathur Rohman, "Ahmad Sirhindī Dan Pembaharuan Tarekat," Wahana Akademika 1, no. 2 (2014): $207-26$.

${ }^{28}$ Najamuddin Amin Al-Kurdi, Tanwir Al-Qulub (Beirut: Dar Al-Fikr, n.d.). 
Education is a golden bridge to achieving high culture. High culture certainly comes from superior human resources that shape cultural image. Education as a systematic effort to establish quality human resources both cognitively and morally and in character. The view of the need for character education based on current teaching education is the tendency of cognitive, memorized and under-applied knowledge. It is important to develop values and moral education for the development of soft skills or character education through strengthening local wisdom, such as Malay literature. ${ }^{29}$

Moral education contained in the local wisdom of the Suluk Tarq Naqsyabandiyah is very interesting to learn where its spiritual activities are to get closer to God by being guided by the teacher (Mursyid). Before someone does suluk, the murshid provides guidance and direction to his students such as the understanding and purpose of suluk. The jama'ah suluk listen and live with hidmah like majlis ta'lim who are located behind the mosque specifically for suluk activities.

The quality of the suluk is reflected in the behavior or morals in daily life. If the morals are in accordance with the morals taught by the prophet then in controlling the Naqsyabandiyah Kholidiyah tarekat itself will have more meaning and even according to a history at a certain maqom level the Salik will feel right in a calm heart, a strong conviction, sincerity accepting destiny God, and no longer prioritize the world.

\section{RESEARCH RESULT}

Moral Education in Suluk Tarekat Naqsyabandiyah Kholidiyah at Pondok Pesantren Al-Manshur Popongan Klaten.

Based on data obtained in the field through observation, interviews and documentation, the writer found that the suluk Tareqat Naqsyabandiyah Kholidiyah in the AlManshur Popongan Islamic Boarding School in Klongan has the impact of moral education as follows:

\section{Morals Towards Allah}

Moral to God is to love Him, thankful for His pleasure, ashamed of Him for immoral behavior, always repent and trust in fear of His doom and always hope for His mercy. ${ }^{30}$

\section{Repentance}

Penance is the beginning of the place of climbing people who climb and the first station for novice Sufis. The nature of repentance according to the meaning of language is "back". The word taba means return, so repentance also means return. That is, returning from something denounced from the Shari'a to something that is praised in Shari'a. ${ }^{31}$

In the presentation that was carried out when the observation of someone who was intent on bathing repentance wished that all sins that had been committed were erased simultaneously the flowing water cleansed his body and performed repentance

\footnotetext{
29 Sudanto Muhammad Faisal, Rafiuddin Afkari, "Transformation of Sufi Teachings in the Malay Literature Sufism: Effort to Strengthening the Character Education Based on Local Wisdom in Kepulauan Riau," in Proceedings of the 1st International Conference on Character Education, 2015, 1-8.

${ }^{30}$ Nur Hidayat, Akidah Akhlak (Yogyakarta: Ombak Dua, 2015).

31 Abul Qasim, Risalah Qusyairiyah (Jakarta: Pustaka Amani, 2007).
} 
prayers in the initial framework to draw closer to Allah, because Allah loved those who repented and those who repented clean person.

Then after the body is clean the heart and deeds are filled with always worshiping Allah who is carrying out God's commands to worship Him in accordance with His commands.

\section{Gratitude}

Gratitude is the attitude of accepting, appreciating (thanking), and utilizing the blessings of God's gifts well, according to God's purpose of giving favors earlier. ${ }^{32}$ Gratitude for a servant consists of three pillars in which all three must be present. Namely: inwardly acknowledging favors, born talking about it and make it as a means to taan to Allah SWT. ${ }^{33}$

Therefore, trying and being grateful are the two sides of the task of human life which are united as a whole in the life activities of every Muslim. People who are never grateful will be those who do not accept limitations in themselves as human beings because it is seen as a person who is in denial, a behavior that is disliked by God.

A person who follows suluk will always remember the creator, namely Allah SWT. Will always be grateful for favors given by God to him. This is proven when a Salik finds satisfaction, when his world affairs are fulfilled and he feels that there are no dependents, the responsibility towards his children and family is already independent.

\section{Tawakal}

Tawakal is to free oneself from all dependence on other than Allah and leave the decisions of everything to Him. ${ }^{34}$ Tawakal is one of the fruits of faith. With trust, his heart will be calm and serene, for he believes in the justice and grace of God Tawakalis not surrender to circumstances, on the contrary tawakal encourages people to work hard because God does not waste human work. After working any work the results will be received as the best for him, not disappointed or discouraged.

Suluk followers realize that deeds of worship are the most important things besides the things or affairs that are done while on earth. To get closer to God requires concentration and atmosphere that makes it more solemn in worship, pray, surrender and always draw closer to Allah SWT in the hope that tomorrow when it is time to get inner peace and help and forgiveness from the almighty God. ${ }^{35}$

\section{Sincere}

Ikblas means to purify the goal of obeying Allah as the only goal in all forms of obedience. Or ignore the views of beings by always concentrating on Khaliq. ${ }^{36}$ Sincerity is the acceptance of pious deeds carried out in accordance with the sunnah of the Prophet

Straight means far from shirk (associating partners with Allah) and far from error. And purify it by always carrying out observance of worship in numbers carrying out the

32 Yusuf, Menjaga Nama Islam (Bandung: Pustaka, 1986).

33 Ibnu Qayyim, Tarkiyah An-Nafs (Solo: Pustaka Arafah, 2001).

${ }^{34}$ Yunahar Ilyas, Kuliah Akblak (Yogyakarta: LPPI, 1999).

35 KH. Multazam Al-Makky., "Hasil Wawancara DenganMursyid Tarekat Di Pondok Pesantren AlManshur Popongan, Popongan Klaten," n.d.

${ }^{36}$ Qayyim, Tazkiyah An-Nafs. 
commands of Allah SWT. In general, a person who follows suluk basically experiences a common goal of not feeling calm and feeling there is no improvement in worship. Then there is the motivation from within to increase the practices given by his teacher, regularly, discipline and consistent (istiqomah) and worship becomes more stable to get closer to God. ${ }^{37}$

According to Islah Gusmian that learning processthe old manuscripts are very important because they contain the meaning of the diversity of the fields of study studied by the students and their unique learning methods. It is here that pesantren have taken an important role in the practice of Islamic learning and at the same time as an important subject in the history of islamization in the archipelago. ${ }^{38}$

In the explanations that the researchers wrote above, we can see from the results of the interview of one of the worshipers who are classified as senior in the initials initials AK. 82 years old. AK has participated in the baiat suluk in 1970 to 2018. Every year following the suluk once counted AK has participated in suluk 48 times over 48 years each year only at the Al-Mansur Islamic Boarding School.

The purpose of AK is worship. AK feels that the needs regarding world affairs are sufficient, that is, seeing his children as independent and working. While AK follows suluk is to get inner peace and help tomorrow on the Day of Judgment, through ta'dzim with scholars and remembrance remember Allah. Before joining Suluk AK, she did not feel calm and felt there was no improvement in worship. Then there is the motivation from within to increase the practices given by his teacher, regularly, discipline and consistent (istiqomah) and worship to get closer to God.

With various midnight rituals, dhikr always remembers Allah by way of dhikr, tawajuhan after the midday and afternoon prayers. While the level of dzikir every 10 days rises once and the students who do Tariqoh are prohibited from borrowing sandals without the knowledge of their owners and in that Tariqoh are given a diploma by the Murshid to always be practiced by the santri as a form of obedience between students and teachers who must always be done. ${ }^{39}$

It is clear that someone who follows a suluk ritual and what he gets leads to an almighty god, including: Repentance, Gratitude, Tawakal and Ikhlas. All four processes have the same emphasis, namely how humans know God and how humans can always be close to God. God is the creator of all things. He created man as well as possible and bestowed a privileged position on humans before His other creations. Such a position is characterized by the provision of thought power, creative ability and moral awareness.

\section{The student's morals towards the teacher.}

Understanding morals to teachers contained in the book Ta'lim Muta'allim by Syaich Az-Zamuji, in the chapter on how to respect science and experts as follows:

${ }^{37}$ KH. Multazam Al-Makky. Hasil wawancara dengan Mursyid Tarekat di Pondok Pesantren AlManshur Popongan Klaten, "Hasil Wawancara Dengan Mursyid Tarekat Di Pondok Pesantren Al-Manshur Popongan Klaten, KH. Multazam Al-Makky.," 2019.

38 Islah Gusmian, "Manuskrip Keagamaan Di Masjid Popongan: Kajian Kodikologi Dan Pemetaan Isi," DINIKA : Academic Journal of Islamic Studies 4, no. 2 (2019): 249-74, https://doi.org/10.22515/dinika.v4i2.2059.

39 Al-Makky., "Hasil Wawancara DenganMursyid Tarekat Di Pondok Pesantren Al-Manshur Popongan, Popongan Klaten,." 


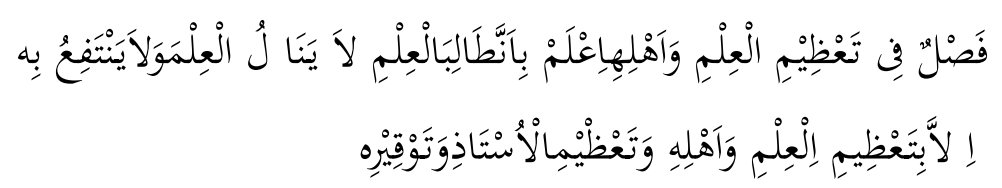

Meaning: "Students (santri) will not gain knowledge and will not be able to take advantage of it, without respecting knowledge and teachers ". 40

So from the explanation above, we can conclude that the only moral for teachers is to glorify and respect them, so that we can benefit later, through certain methods. As the researchers found in the implementation of the Naqsyabandiyah Kholidiyah Suluk Tarekat in the Al-Manshur Popongan Islamic Boarding School in Klaten.

In addition in the implementation of suluk there are some morals that researchers meet, including:

Ridho i.e., accepting with pleasure what Allah is bestowed. ${ }^{41}$ But in this context it is aimed at students and teachers or Murshid. In this context what is meant by accepting happily what is instructed or taught by his teacher. Then there is no one who guides and teaches the essential good, if that happens it will cause enormous losses. By giving examples and liking and stories to instill moral education from an early age can be considered successful and successful.

$T a^{\prime} d$ rim means very respectful and polite by paying attention to the behavior and manners of a student to the teacher. ${ }^{42}$ In dealing with a teacher, then students must implement the principles of good manners in accordance with the position as people who need the wisdom of knowledge. The courtesy includes: obedience and respect for the teacher, honoring the teacher and persevering in taking the lesson seriously. (Risalatul Mubarakah) ${ }^{43}$ This student must have respect and obedience to a teacher, both naturally and mentally and will not believe the scientific degree possessed by his teacher. As an illustration of how much influence the teacher has on his students can be seen the effect of deflecting the nature that is placed on humans. How great and influential is the result of the morals of Masyaich, especially when the relationship with them is in accordance with the relationship and the procedure of instilling values and receiving spiritual light when tawajuhan. It can be seen from the faith and ihksan of the companions of the prophets because the influence of being together with their prophets gained the spiritual light of the Prophet in their hearts.

Obedient in language means to always obey or obey, to the teacher's orders and always obey the rules given by him. Ask well, too. The existence of teachers or often referred to as Murshid is able to provide knowledge through exemplary education that can provide an explanation of the process of interaction between students and teachers that are reviewed not only from school education but the educational process in the ritual

\footnotetext{
${ }^{40}$ Syaich Az-Zamuji, Ta'lim Muta'allim (Surabaya: Mutiara Ilmu, 1995).

${ }^{41}$ Sumantri, Akblak Tasawuf (Surakarta: Pegangan Kuliah Fakultas PAI UMS, 1997).

42 Al-Makky., "Hasil Wawancara DenganMursyid Tarekat Di Pondok Pesantren Al-Manshur Popongan, Popongan Klaten,."

43 Hasil observasi Pondok Pesantren Al-Manshur Popongan Klaten, "Hasil Observasi Pondok Pesantren Al-Manshur Popongan Klaten," n.d.
} 
of suluk attachment is very important in this regard. ${ }^{44}$ In the above context, it is only that the sense of obedience in submitting property, soul, body, may not be prejudiced by workers towards the behavior of the teacher even though it has violated the Sharia. But it must be ta'wil or interpreted and meant that it is the best and must be according to what the teacher ordered both in terms of worship or muamalah.

Trustful namely honest and trustworthy. ${ }^{45}$ So we can conclude that the mandate is an honest and trustworthy attitude to maintain mutual interaction between personal relationships between students and teachers both the advantages and disadvantages of the teacher. He should not acknowledge the shortcomings of his teacher as a mistake, and he should also not tell others. If the shortcomings have disappeared, and the teacher has moved back to its original high level. He is not in a constant state of deprivation. However, lack is solely due to oversight, and because of an event which separates two things. From the words of the wise above turns out to be in accordance with the theories put forward by experts. Among the many theories or methods that emerged, ${ }^{46}$ This is where the moral education based on suluk tarekat educates with the exemplary method. Broadly speaking, from some of the moral contexts related to the morals of a student to the teacher is nothing but to get closer and get along with him, because by always getting closer to the teacher the child can receive knowledge and advice.

\section{Moral to yourself.}

Understanding morals to oneself found in the book Al-Muta'allimi wal mu'allimi Karya H. Taufiqul Hakim, in the chapter on morals to yourself as follows:

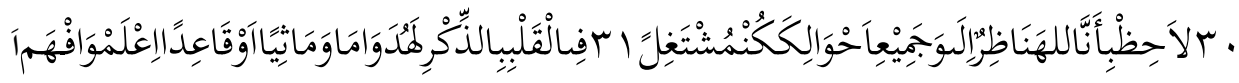

Meaning: 30. Know that God always sees you in every deed. 31.Maka students must always dhikr in his heart, whether when walking, sitting or standing, anywhere and anytime. ${ }^{47}$

Understanding morals to yourself contained in the 30th and 31st books of the Adabul Muta'allim wal Mu'allim, the Work of H. Taufiqul Hakim. In the chapter on santri adab on ourselves. We can conclude that, the moral understanding of ourselves is that we must always remember God and be careful when carrying out activities in daily life, because we are always supervised by God at all times.

From the information above, the researcher can submit morality to oneself in the Suluk of the Naqsyabandiyah Kholidiyah Congregation, Klongan Al-Manshur Islamic Boarding School, which includes:

Sidiq Sidiq understanding according to Sayyid Muhammad contained in the book Tahliyyah Watarghib which reads:

\footnotetext{
44 Klaten.

45 Al-Makky., "Hasil Wawancara DenganMursyid Tarekat Di Pondok Pesantren Al-Manshur Popongan,

${ }^{46}$ Klaten, "Hasil Observasi Pondok Pesantren Al-Manshur Popongan Klaten."

47 Taufiqul Hakim, Adabul Muta 'Allim Wal Mu'Allim (Jepara: P.P Darul Falah, 2013).
} Popongan Klaten,.” 


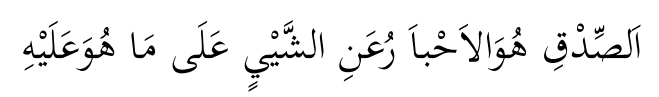

Meaning: "Sidik is giving news according to what happened ".48

From the description above the researcher can conclude that the notion of fingerprints is telling the truth in accordance with reality. To form people who are virtuous, strong-willed, polite in speech and deeds, noble in behavior and civilized, then the process of moral education that will always guide and direct humans in actualizing good moral behavior in everyday life.

Which is included in the context in the book above Tahliyyah Watarghib contained in the first point that is feeling supervised by Allah SWT in every behavior that we do, this means stressing us to always be honest (as is). In terms of material content, in the ritual of suluk moral education "Naqshbandiyah Kholidiyah tariqa" which is in the boarding house of Al-Mansur is more directed towards moral development in oneself. If it is adjusted with the scope of moral education materials oriented towards moral enforcement, then it can be seen as follows: the development of democratic values is contained in the materiality of meeting, studying, discussing and studying.

Mujahadah, The definition of Mujahadah according to Sayyid Bakri Al-Makky contained in the Kifayah Atqiya 'Wa Min Hajul Ashfiyak which reads:

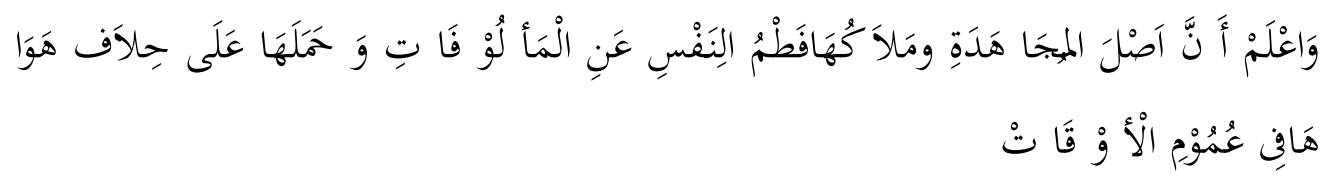

Meaning: "The essence of mujahadah is to restrain the desires of everything that is desired and be able to resist the desires or passions throughout its time. ". ${ }^{49}$

From the description above, the researcher can conclude that the definition of mujahadah is to restrain the desires and desires that plunge into sleaze. Mujahadah is a strong desire that gives birth to a burning inner struggle. Mujahadah is an inner struggle, an elan (spirit) that is full of sincerity (jihad) and constantly knocks the heart, in order to maintain the divine light that resides in the heart so that it is not easily trapped by the snares of the devil. ${ }^{50}$

Mujahadahmore swooping in, to get intrinsic knowledge (makrifat), so that he always gets and is on the road in accordance with the instructions (huda) of the light of truth. By prioritizing worship to Allah SWT and avoiding immorality that results far from its pleasure.

${ }^{48}$ Sayyid Muhammad, Tabliyyah Watarghib (Surabaya: Maktabah, n.d.).

${ }^{49}$ Sayyid Bakri, Kifayahtul Atqiya’ Wa Min Hajul Ashfiya' (Libanon: Beirt, n.d.).

50 Toto Tasmara, Kecerdasan Rohaniah (Depok: Gema Insani, 2001). 


\section{Istiqomah}

Istiqomah is fixed in the faith and obedient to Allah SWT and is on the right path towards Allah SWT. ${ }^{51}$ Improving the quality of morals in oneself, using hands to give to others in need, may not take goods that are not and belong. The feet are used to go to Allah's blessed place while the mouth is used by speaking honestly, kind and polite not backbiting, swearing and so on, so if it is used properly for remembrance remembering Allah then the side will be high in degree.

While that is found in the manners or morals of a student to himself in the book Risalatul Mubarakah. Aim which includes moral education in general is the achievement of world happiness and akherat from the knowledge possessed by humans, so that human beings become perfect, morally virtuous, strong-willed, polite in speaking and doing, noble in behavior and capable civilized shoulder the burden and responsibility given to humanity. ${ }^{52}$

Wara'

Literally al-wara 'means pious, distance from the sinful deeds. ${ }^{53}$ This is where the role of humans as earthly caliphs who get the mandate to always believe in and fear God. As a perfect creature of God, you should be grateful for the blessings that Allah has given. Having five senses that are complete in accordance with the needs, then to reach the pleasure of Allah SWT is not just worship but also must be implemented by guarding it properly, utilizing the five senses in accordance with the rules and prohibitions ordered, as an expression of tawaduk (feeling inferior) and supervised by God .

Thus we feel we know ourselves as a creature with many deficiencies. Therefore we should not be arrogant and feel more in front of others. This is in line with one of the interview data which researchers had to dig up information, namely Salik with the initials SH. 66 years old. SH came from a Javanese tribe who lived in Ngawi, East Java. SH is a retired TNI. One informant followed suluk baiat 4 times. Every year following suluk once counted $\mathrm{SH}$ has participated in suluk as many as 4 times over 66 years each year only at the boarding school Al-Mansur.

\section{Morals towards fellow human beings}

Understanding morals to yourself contained in the book Al-muta'allimi wal mu'allimi by H. Taufiqul Hakim, in the chapter on morals to others as follows:

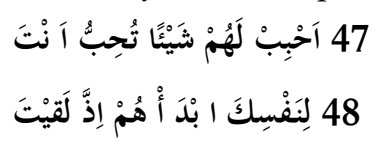

Meaning: "Love your friends, Muslims. As you love yourself". 54

${ }^{51}$ Hasil wawancara dengan Mursyid Tarekat di Pondok Pesantren Al-Manshur Popongan Klaten, "Hasil Wawancara Dengan Mursyid Tarekat Di Pondok Pesantren Al-Manshur Popongan Klaten, KH. Multazam AlMakky."

${ }^{52}$ Kh. Hambali Sumardi, Risalatul Mubarakah (Kudus: Menara Kudus, 1965).

${ }^{53}$ Nasrul, Akblak Tasawuf (Yogyakarta: Aswaja Presindo, 2015).

${ }^{54}$ Nasrul. 
Understanding morals to yourself contained in nadhom 37 and 38 of the book Adabul Muta'allim wal Mu'allim, the Work of H. Taufiqul Hakim. In chapters there are students on themselves. We can conclude that, the moral understanding of our fellow humans is that we must always love our neighbors as we love ourselves, because in fact fellow Muslims are brothers. Such as: mutual respect, help and tolerance.

Actualization of moral education in the life of the Popongan Al-Manshur Islamic Boarding School in Klaten.

Human relations with each other include one's relationship with family and one's relationship with the community. ${ }^{55}$ Based on interviews and observations in the field of actualization of suluk towards the popongan community, even though some of them participated in tareqat. Significantly it is not so influential, however, in matters of spirituality or worship is more or less influential. For example at the beginning of the mosque when the day outside the implementation of suluk, the situation was quiet with the emergence of suluk activities becoming crowded, many people celebrated or recited the mosque which made the spirit of the atmosphere lively. ${ }^{56}$

Besides that, with the large number of pious people performing the ritual, blessing and prayer always envelop the community around the Klongan Boarding School Al-Manshur Islamic Boarding School. However, the implementation of the suluk itself is mostly, its followers from the area outside the Al-Mashur Islamic Boarding School in Klongan Popongan itself, of course, influencing the environment or areas of the participants of the suluk respectively

In essence the ritual of suluk for several days, where the period is a "formulation" of the soul in which there is a process of self-reflection. How is the quality of hablumminallah, if it succeeds with the indicator of the suluk actor becoming more "sumeleh" in a moment, then his management in managing life and managing hablumminannas also becomes more qualified or more careful in maintaining relationships with others. ${ }^{57}$ If related to the information above, of course, Salik should respect each other and respect each other, feel a sense of togetherness in worship, and ask questions in a good way.

Therefore, researchers can conclude that the actualization of moral education in the suluk of the naqsyabandiyah kholidiyah tarekat in the Boarding School of Al-Mansur Popongan Klaten includes:

\section{Ukhuwah Islamiyah}

Respect for friends and friends is a praiseworthy attitude in Islam. ${ }^{58} \mathrm{At}$ the time of suluk activities researchers found, when meeting or dealing with one another. Then among the suluk participants did not forget to say and answer greetings. ${ }^{59}$ This can be realized in social life such as the habits contained in the ritual suluk. Get to know each other, not only just the

\footnotetext{
${ }^{55}$ Hidayat, Akidah Akblak.

${ }^{56}$ Samsul Munir Amin, Ilmu Akblak (Jakarta: AMZAH, 2016).

${ }^{57}$ Al-Makky., "Hasil Wawancara DenganMursyid Tarekat Di Pondok Pesantren Al-Manshur Popongan, Popongan Klaten,."

58 Afrizal, Metode Penelitian Kualitatif.

${ }^{59}$ Hasil wawancara dengan Mursyid Tarekat di Pondok Pesantren Al-Manshur Popongan Klaten, "Hasil Wawancara Dengan Mursyid Tarekat Di Pondok Pesantren Al-Manshur Popongan Klaten, KH. Multazam AlMakky."
} 
physical ta'aruf or ordinary identity, but also further the background ta'aruf, ideas and ideals and problems encountered. Respect in Islam is: by saying "Assalamu'alaikum", if you meet someone, greet each other between the young to the old and the old to the young, anywhere, anytime while still meeting and face to face. ${ }^{60}$

\section{Tawadhu'}

Definition of Tawadhu etymologically, the word tawadhu is derived from the word wadh'a which means to degrade, and comes from the word "ittadha'a" with the meaning of demeaning. Besides that, the word tawadhu is also interpreted lowly towards something. While in terms of, tawadhu is to show humility to something that is exalted. In fact, there are also interpreted tawadhu as an act of glorifying people because of their primacy, accepting the truth and so on. ${ }^{61}$

Tawadhu is maintaining relationships and relationships with fellow human beings, without feeling exaggerated oneself in front of others. ${ }^{6}$ Tawadhu 'means humble, the opposite of arrogant or arrogant. People who are humble do not look at themselves more than other people, while arrogant people overestimate themselves. Humility is not the same as inferiority. Even in practice, an inferior person means losing confidence. Even though in practice people who are humble tend to humble themselves in front of others, but this attitude is not born from insecurity. ${ }^{63}$

Signs of people who Tawadhu 'to humans include: 1. Receiving advice / advice from the truth of others, 2. Always see the strengths of his brother, and try to cover up the shortcomings. 3. Ready to help others. 4. Consult with other community members. 5. Always be kind thinking (khusnudzan) to others. ${ }^{64}$

Andap asor, this can be observed by researchers when in the conversations between the tone of the speech or the style of the suluk participants, no one spoke excessively. In the sense of talking about wealth or success when in a suluk ritual, he feels himself less than perfect when compared to others. ${ }^{65}$

\section{Ta'awun}

Ta'awnis the attitude of helping others. In this life, there is no one who does not need help from others. Basically, humans are social creatures. Therefore, humans cannot live alone. He needs help and help from others, even if he is rich or has a high position. ${ }^{66} \mathrm{Ta}$ 'awun is helping each other. The strong helps the weak, the strong have the advantage of helping the weak. ${ }^{67}$ Humans are individual beings not social beings. Islam teaches the balance of human life in relation to Allah. (vertical relations) and with fellow humans and nature (horizontal

${ }^{60}$ Departemen Agama RI, Al-Qur'an Dan Terjemahanya (Bekasi: Cipta Bagus Segara, 2013).

${ }^{61}$ Ismail Thalib, Risalah Akblak (Yogyakarta: CV. Bina Usaha, 1992).

${ }_{62}$ Amin, Ilmu Akblak.

${ }_{63}$ Amin.

${ }^{64}$ Amin.

${ }^{65}$ Klaten, "Hasil Observasi Pondok Pesantren Al-Manshur Popongan Klaten."

66 Amin, Imu Akblak.

${ }^{67}$ Nor Hasan, "Fullday School (Model Alternatif Pembelajaran Bahasa Asing)," Jurnal Tadris Stain Pamekasan Vol 1, no. No 1 (2006) (2006): 109-18. 
relations). Good morals to Allah. and His Messenger, then to yourself is not enough if it is not accompanied by good morals to fellow human beings. ${ }^{68}$

In this life, everyone must need help from others. because in Islam a Muslim who is one with another is like a building. So if one community is affected by disaster, then the other people are obliged to help. ${ }^{69}$ This is as expressed by one of the worshipers of suluk, about the benefits of suluk in the sphere of society that is more addressing pluralism in society, because suluk itself aims to get closer to God and soften hearts. Therefore, what is felt when outside the cottage there is more stimulation or concern for others. ${ }^{70}$

\section{Husnudzan}

Husnuz?hanit means good thinking, jokes are su'uzzhan (evil thinking). Evil thought that the law was unlawful, believing that his heart was unanimous in accusing his brother of being a bad person, whereas he himself did not fully know his brother's actions or hearts. ${ }^{71}$

Husnuz:han is maintaining relationships and relationships with fellow human beings, without feeling exaggerated oneself in front of others. ${ }^{72}$ People who are good morals are those who are: friendly, not hurting other people's hearts, not lying, saying little to much work, not slandering and his words are liked by others. ${ }^{73}$ Including the morals of neighbors, good relations must continue to take precedence and avoid gossip and slander. ${ }^{74}$

\section{CONCLUSION}

Based on the results of the research and analysis above, the moral values contained in the suluk tarekat / naqsyabandiyah kholidiyah are as follows: Moral Education in the Suluk Procession of the Naqsyabandiyah Kholidiyah Congregation of Al-Manshur Popongan Klaten Islamic Boarding School. Based on the content of the terms and pillars of the above sulukasa that in the procession of suluk there are moral education values that are able to improve the quality of human beings to be perfect beings. And in it there are morals towards Allah SWT, Teachers, Students and Fellow. The implementation of suluk can also be actualized in social life. Values of moral education in the Sulq Naqsyabandiyah Kholidiyah tarekat Pondok Pesantren Al-Mansur Popongan Klaten. That contains moral education which includes: 1. Morals with God, namely Repentance, Gratitude, Tawakal, and Ikhlas. 2. Morals towards Teachers, namely Ridho, Ta'dzim, Obedience and Amanah. 3. Morals towards Yourself, namely Sidiq, Mujahadah, Istiqomah and Wara '. 4. Morals towards Others, Implementation of Suluk Naqsyabandiyah Kholidiyah in Community or Daily Life. 1. Ukhuwah Islamiyah, 2. Tawadhu ', 3. Ta'awun and 4. Hunuzzan

${ }^{68}$ M. Syamsul, “"Nilai-Nilai Akhlak Dalam Suluk Linglung Dan Relevansinya Dalam Pendidikan Islam"," Episma 24, no. 2 (2015): 1-15.

${ }^{69}$ Hidayat, Akidah Akblak.

${ }^{70}$ Klaten, "Hasil Observasi Pondok Pesantren Al-Manshur Popongan Klaten."

${ }^{71}$ Akhmad Sagir, Husnuzzhan (Yogyakarta: Mitra Pustaka, 2011).

72 Amin, Imu Akblak.

${ }^{73}$ Oemar Bakri, Akblak Muslim (Bandung: Angkasa, 1993).

${ }^{74}$ M. Abdurrahman, Akblak Menjadi Seorang Muslim Berakblak Mulia (Depok: Raja Grafindo persada, 2010). 


\section{REFERENCES}

Abdullah, Luqman. "Kontribusi Tarekat Naqsabandiyah Terhadap Pendidikan Agama Islam Dan Perubahan Perilaku Sosial Jamaah.” Nąhruna 1, no. 1 (February 23, 2018): 1-13. http://e-journal.ikhac.ac.id/index.php/NAZHRUNA/article/view/82.

Abdurrahman, M. Akblak Menjadi Seorang Muslim Berakblak Mulia. Depok: Raja Grafindo persada, 2010.

Abdurrahman, Nana Herdiana. "Character Education in Islamic Boarding School- Based Sma Amanah.” Jurnal Pendidikan Islam 2, no. 2 (June 21, 2016): 287-305. https://doi.org/10.15575/jpi.v2i2.791.

Afrizal. Metode Penelitian Kualitatif. Depok: Raja Grafindo, 2014.

Al-Kurdi, Najamuddin Amin. Tanwir Al-Qulub. Beirut: Dar Al-Fikr, n.d.

Al-Makky., KH. Multazam. "Hasil Wawancara DenganMursyid Tarekat Di Pondok Pesantren Al-Manshur Popongan, Popongan Klaten," n.d.

Al-Syaibany, Omar Muhammad al-Toumy. Falsafah Pendidikan Islam (Terj. Hasan Langgulung). Cet. I. Jakarta: Bulan Bintang, 1979.

Amin, Samsul Munir. Ilmu Akblak. Jakarta: AMZAH, 2016.

Amri, Muhammad, Saharuddin Saharuddin, and La Ode Ismail Ahmad. "The Implementation of Islamic Education: The Process of Instilling Akhlakul Karimah (Noble Characters) for Madrasah Tsanawiyah Students." Tadris: Jurnal Keguruan Dan Imu Tarbiyah 4, no. 1 (June 28, 2019): 117-25. https://doi.org/10.24042/tadris.v4i1.4070.

Annemarie Schimmel. Mystical Dimensions of Islam. Jakarta Selatan: Mizan, 2013.

Anwar, Chairul, Antomi Saregar, Uswatun Hasanah, and Widayanti Widayanti. "The Effectiveness of Islamic Religious Education in the Universities: The Effects on the Students' Characters in the Era of Industry 4.0." Tadris: Jurnal Keguruan Dan Ilmu Tarbiyah 3, no. 1 (June 29, 2018): 77-87. https://doi.org/10.24042/tadris.v3i1.2162.

Arifin, Arifin, Hasan Asari, and Amroeni Drajat. "The System of Spiritual Education of Tarekat Sammaniyah at Learning Assembly of Ihya Ulumuddin Medan." International Journal on Language, Research and Education Studies 1, no. 1 (2017): 34-52.

Arifin Arifin, Hasan Asari, and Amroeni Drajat. "The System of Spiritual Education of Tarekat Sammaniyah At Learning Assembly of Ihya Ulumuddin Medan.” International Journal on Language, Research and Education Studies 1, no. 1 (2017): 34-53. https://doi.org/10.30575/2017081204.

Aripudin, Acep. "Tarekat Qadariyah In Indonesia: Da Wa , Education and Business." Tasamub 12, no. 1 (2014): 1-20.

Az-Zamuji, Syaich. Ta’lim Muta'allim. Surabaya: Mutiara Ilmu, 1995.

Baharun, Hasan, and Rohmatul Ummah. "Strengthening Students' Character in Akhlaq Subject Through Problem Based Learning Model." Tadris: Jurnal Keguruan Dan Ilmu Tarbiyah 3, no. 1 (June 29, 2018): 21-30. https://doi.org/10.24042/tadris.v3i1.2205.

Bakri, Oemar. Akblak Muslim. Bandung: Angkasa, 1993.

Bakri, Sayyid. Kifayabtul Atqiya' Wa Min Hajul Ashfiya'. Libanon: Beirt, n.d.

Chittick, William C. "On the Cosmology of Dhikr." Within Paths to the Heart: Sufism and the Christian East (Edt. James S. Cutsinger), Indiana: World Wisdom, 2004, 55-56. 
Creswell, John W. Qualitative Inquiry \& Research Design: Choosing among Five Approaches. 2nd ed. Thousand Oaks: Sage Publications, 2007.

Dkk, Umam U. Metode Penelitian Agama: Teori Dan Praktek. Jakarta: Raja Grafindo, 2006.

Faiz, M. "Unsur Sufisme Dalam Konsep Pendidikan Said Nursi." Nižham 4, no. 2 (2015).

Firdaus, Firdaus. "Tarekat Qadariyah Wa Naqsabandiyah: Implikasinya Terhadap Kesalehan

Sosial." Al-Adyan 12, no. 2 (January 5, 2018): 55-72.

https://doi.org/10.24042/adn.v12i2.2109.

Gusmian, Islah. "Manuskrip Keagamaan Di Masjid Popongan: Kajian Kodikologi Dan Pemetaan Isi." DINIKA: Academic Journal of Islamic Studies 4, no. 2 (2019): 249-74. https://doi.org/10.22515/dinika.v4i2.2059.

Hakim, Taufiqul. Adabul Muta 'Allim Wal Mu'Allim. Jepara: P.P Darul Falah, 2013.

Hasan, Nor. "Fullday School (Model Alternatif Pembelajaran Bahasa Asing)." Jurnal Tadris Stain Pamekasan Vol 1, no. No 1 (2006) (2006): 109-18.

Hasil wawancara dengan Mursyid Tarekat di Pondok Pesantren Al-Manshur Popongan Klaten, KH. Multazam Al-Makky. "Hasil Wawancara Dengan Mursyid Tarekat Di Pondok Pesantren Al-Manshur Popongan Klaten, KH. Multazam Al-Makky.," 2019.

Hidayat, Nur. Akidah Akblak. Yogyakarta: Ombak Dua, 2015.

Ilyas, Yunahar. Kuliah Akblak. Yogyakarta: LPPI, 1999.

Isa, Amrizal, and Riki Astafi. "The Existing of Naqshbandi Tariqa and Its Influence on Socio-

Cultural Life of the Sakai People in Bengkalis Regency." Wawasan: Jumal Ilmiah Agama Dan Sosial Budaya 4, no. 1 (2019): 80-93. https://doi.org/10.15575/jw.v4i1.4072.

Istadiyantha. Tarekat Syattariyah. Solo: Bina Insani Press, 2007.

Jainudin, Jainudin. "Pendidikan Karakter Dan Pergeseran Sosiopsikologis Penganut Aliran Tarekat Qadiriyahwanaqsabandiyah Surabaya." JOIES: Journal of Islamic Education Studies 1, no. 2 (December 4, 2016): 247-76. http://joies.uinsby.ac.id/index.php/joies/article/view/13.

Klaten, Hasil observasi Pondok Pesantren Al-Manshur Popongan. "Hasil Observasi Pondok Pesantren Al-Manshur Popongan Klaten," n.d.

Ma`arif, Muhammad Anas, and Muhammad Husnur Rofiq. "Dzikir Dan Fikir Sebagai Konsep Pendidikan Karakter: Telaah Pemikiran KH. Munawwar Kholil Al-Jawi." Tadrib 5, no. 1 (July 1, 2019): 1-20. https://doi.org/10.19109/tadrib.v5i1.3066.

Maarif, Muhammad Anas, Muhammad Mujtaba Mitra Zuana, Siti Maryam Munjiat, Ibnu Rusydi, Ali Miftakhu Rosyad, and Lu'lu'il Maknuun. "Character Education Through Dhikr Tariqa Qadiriyya Naqhsabandiyya Al-Usmaniyya Indonesia." Hampstead Psychological Associates 24, no. 07 (2020): 9.

Mahyunir. "Pemikiran Al-Ghozali Seputar Tradisi Sufi.” Nið̧ham 4, no. 2 (2015): 1-20.

Muhammad Faisal, Rafiuddin Afkari, Sudanto. "Transformation of Sufi Teachings in the Malay Literature Sufism: Effort to Strengthening the Character Education Based on Local Wisdom in Kepulauan Riau." In Proceedings of the 1st International Conference on Character Education, 1-8, 2015.

Muhammad, Sayyid. Tabliyyah Watarghib. Surabaya: Maktabah, n.d.

Nasr, Seyyed Hossein. Islamic Philosophy from Its Origin to the Present: Philosophy in the Land of Prophecy. SUNY Series in Islam. Albany: State University of New York Press, 2006. 
Traditional Islam in the Modern World. 1st pbk. ed. London; New York: K. Paul International : Distributed by Routledge, Chapman \& Hall, 1990.

Nasrul. Akblak Tasawnf. Yogyakarta: Aswaja Presindo, 2015.

Qasim, Abul. Risalah Qusyairiyah. Jakarta: Pustaka Amani, 2007.

Qayyim, Ibnu. Tazkiyah An-Nafs. Solo: Pustaka Arafah, 2001.

Redaksi, Dewan. Ensiklopedi Islam. Cetakan II. Jakarta: Ikhtiar Baru Van Hoeve, 1994.

RI, Departemen Agama. Al-Qur'an Dan Terjemahanya. Bekasi: Cipta Bagus Segara, 2013.

Rohman, Fathur. "Ahmad Sirhindī Dan Pembaharuan Tarekat." Wahana Akademika 1, no. 2 (2014): 207-26.

Sagir, Akhmad. Husnuz:̧han. Yogyakarta: Mitra Pustaka, 2011.

Solihin, Rosihon Anwar. Ilmu Tasawuf. Bandung: Pustaka Setia, 2008.

Sudjana, Nana. Pembinaan Dan Pengembangan Kurikulum Di Sekolah. Bandung: Sinar Baru Al Gensindo, 1991.

Sugiyono. Metode Penelitian Kuantitatif, Kualitatif Dan R\&D. Bandung: CV. Alfabeta, 2011. . Metode Penelitian Kuantitatif Kualitatif Dan R\&D. Bandung: Alfabeta, 2015.

Suharsimi. Prosedur Penelitian. Jakarta: Rineka Cipta, 2014.

Sumantri. Akblak Tasawuf. Surakarta: Pegangan Kuliah Fakultas PAI UMS, 1997.

Sumardi, Kh. Hambali. Risalatul Mubarakah. Kudus: Menara Kudus, 1965.

Syamsul, M. "'Nilai-Nilai Akhlak Dalam Suluk Linglung Dan Relevansinya Dalam Pendidikan Islam".” Episma 24, no. 2 (2015): 1-15.

Tasmara, Toto. Kecerdasan Rohaniah. Depok: Gema Insani, 2001.

Taufiq, Moh. "Pola Pendidikan Berbasis Tareqat Qadiriyah Wan Naqsabandiyah Di Pondok Pesantren Assalafi Al-Fitrah Surabaya." Jurnal Pendidikan Agama Islam Journal of Islamic Education Studies) 5, no. 1 (May 2, 2017): 138-60. https://doi.org/10.15642/jpai.2017.5.1.138-160.

Thalib, Ismail. Risalah Akblak. Yogyakarta: CV. Bina Usaha, 1992.

Yusuf. Menjaga Nama Islam. Bandung: Pustaka, 1986.

Zamhari, Arif. "THE MAJLIS DHIKR OF INDONESIA: Exposition of Some Aspects of Ritual Practices." JOURNAL OF INDONESIAN ISLAM 3, no. 1 (June 1, 2009): 122-147-147. https://doi.org/10.15642/JIIS.2009.3.1.122-147. 